\title{
PENTINGNYA MELATIH KEMANDIRIAN ANAK
}

\author{
Rika Sa'diyah \\ FAI-Universitas Muhammadiyah Jakarta \\ Jln KH. Ahmad Dahlan, Cireundeu,Ciputat Jakarta 15419 \\ Email: ikafina@gmail.com
}

\begin{abstract}
The Importance of Training Children's Independence. A critical factor in the growth of the child one of them is independence. Children who have independence in learning activities look active, have perseverance and initiative in doing tasks, well strategies in learning, have responsibility, be able to manage behavior and cognition and have self-confidence. Self-reliance is the ability to direct and control oneself in thinking and acting, and emotionally not feeling dependent on others, in the sense that a kid who independent will not depend on the help of others in taking care of himself physically, in making decisions emotionally and in interacting socially with others demonstrated by children doing simple things, initiating, trying new things, obeying rules and playing with peers, and feeling secure, comfortable and self-controlling. In practical independence is the ability of children to think and do things by themselves to meet their needs so they no longer rely on others and become an independent individual.
\end{abstract}

Keywords: Training, Independence, Children Self Independence

Abstrak: Pentingnya Melatih Kemandirian Anak. Faktor penting dalam tumbuh kembang anak salah satunya adalah kemandirian. Anak yang memiliki kemandirian dalam kegiatan belajar terlihat aktif, memiliki ketekunan dan inisiatif dalam mengerjakan tugas-tugas, menguasai strategi-strategi dalam belajar, memiliki tanggung jawab, mampu mengatur perilaku dan kognisinya serta memiliki kayakinan diri. Kemandirian merupakan kemampuan untuk mengarahkan dan mengendalikan diri sendiri dalam berpikir dan bertindak, serta tidak merasa bergantung pada orang lain secara emosional, dalam arti anak yang mandiri tidak akan tergantung pada bantuan orang lain dalam merawat dirinya secara fisik, dalam membuat keputusan secara emosi dan dalam berinteraksi dengan orang lain secara sosial yang ditunjukkan dengan anak melakukan hal sederhana, inisiatif, mencoba hal baru, mentaati peraturan dan bermain dengan teman sebaya, dan merasa aman, nyaman dan mampu mengendalikan diri. Secara praktis kemandirian adalah kemampuan anak dalam berpikir dan melakukan sesuatu oleh diri mereka sendiri untuk memenuhi kebutuhannya sehingga mereka tidak lagi bergantung pada orang lain namun dapat menjadi individu yang dapat berdiri sendiri.

Kata kunci: Melatih, Kemandirian, Kemandirian Anak 


\section{Pendahuluan}

Pendidikan anak merupakan pendidikan yang paling mendasar menempati posisi yang sangat strategis dalam pengembangan sumber daya manusia. Rentang anak usia dini adalah dari lahir sampai delapan tahun merupakan rentang usia kritis dan sekaligus strategis dalam proses pendidikan yang dapat mempengaruhi proses serta hasil pendidikan pada tahap selanjutnya. Periode ini merupakan periode kondusif untuk menumbuhkembangkan serta melatih dan mengajarkan berbagai potensi kemampuan dasar anak yang salah satunya adalah melatih kemandirian anak.

Kemandirian merupakan suatu sikap yang diperoleh secara kumulatif melalui proses yang dialami seseorang dalam perkembangannya, dimana dalam proses menuju kemandirian, individu belajar untuk menghadapi berbagai situasi dalam lingkungan sosialnya sampai ia mampu berpikir dan mengambil tindakan yang tepat dalam mengatasi setiap situasi. Aktivitas bersama membantu anak untuk menanamkan cara berfikir dan bersikap di masyarakat dan menjadikannya sebagai caranya sendiri. Orang dewasa (teman sebaya yang lebih tua) seharusnya membantu mengarahkan dan mengorganisasi proses pembelajaran anak sehingga anak mampu menguasai dan menginternalisasikan secara mandiri.

Menurut pandangan teori psikososial Erikson, faktor sosial dan budaya berperan dalam perkembangan manusia, termasuk di dalamnya perkembangan kemandirian anak. Menurut Erikson, perkembangan manusia sebaiknya dipahami sebagai interaksi dari tiga sistem yang berbeda yaitu: sistem somatik, sistem ego, dan sistem sosial. Sistem somatik terdiri dari semua proses biologi yang diperlukan untuk berfungsinya individu. Sistem ego mencakup pusat proses untuk berpikir dan penalaran; dan sistem sosial meliputi proses dimana seseorang menjadi bagian dalam masyarakatnya.

Berdasarkan uraian di atas, dapat disimpulkan bahwa kemandirian perlu diajarkan dan dilatihkan sedini mungkin, yaitu semenjak anak batita bayi tiga tahun, dimana anak sudah mulai banyak berinteraksi dengan orang lain, tidak hanya dengan orang terdekatnya (ibu dan ayah) tapi juga sudah mulai berinteraksi dengan orang-orang yang baru dikenalnya, disinilah waktu yang tepat untuk bersosialisasi sekaligus melatih dan mengajarkan kemandirian pada anak. 
Pembahasan pentingnya melatih dan mengajarkan kemandirian pada anak dalam tulisan ini, mencakup tentang hakikat kemandirian, ciri-ciri kemandirian anak, aspek-aspek kemandirian anak, faktor-faktor yang mempengaruhi kemandirian anak, melatih kemandirian anak, kemandirian dan harga diri yang diakhiri dengan penutup atau kesimpulan.

\section{Hakikat Kemandirian}

Pada saat dilahirkan, manusia dalam keadaan tidak berdaya, namun di balik ketidakberdayaannya tersebut menyimpan potensi yang besar untuk dikembangkan. Untuk dapat berkembang secara wajar, seseorang memerlukan bantuan orang lain guna membimbing dan mengarahkan perkembangan potensi tersebut. Bantuan orang lain tersebut dapat berasal dari keluarga, lembaga pendidikan, dan masyarakat luas. Pengetahuan, keterampilan, nilai-nilai serta sikap yang dimiliki sebagain besar diperoleh melalui proses interaksi dengan lingkungan. Dalam perkembangan lebih lanjut, manusia tidak dapat hanya mengandalkan bantuan orang lain. Keberhasilan seseorang banyak ditentukan oleh individu yang bersangkutan, paling tidak ditentukan oleh kekuatan, keinginan dan kemauan. Disinilah setiap individu dituntut kemandiriannya dalam melakukan setiap tindakan.

Kemandirian berasal dari kata mandiri, dalam bahasa Jawa berarti berdiri sendiri. Kemandirian dalam arti psikologis dan mentalis mengandung pengertian keadaan seseorang dalam kehidupannya yang mampu memutuskan atau mengerjakan sesuatu tanpa bantuan orang lain. Kemampuan demikian hanya mungkin dimiliki jika seseorang berkemampuan memikirkan dengan seksama tentang sesuatu yang dikerjakannya atau diputuskannya, baik dalam segi-segi manfaat atau keuntungannya maupun segi-segi negatif dan kerugian yang akan dialaminya. ${ }^{1}$

Kemandirian bertitik tolak pada paradigma yang menyatakan bahwa setiap individu atau kelompok bertanggung jawab atas kehidupannya sendiri. Stein dan Book menyatakan bahwa kemandirian merupakan kemampuan untuk mengarahkan dan mengendalikan diri sendiri dalam

${ }^{1}$ Hasan Basri, Remaja Berkualitas Problematika Remaja dan Solusinya (Yogyakarta: Pustaka Pelajar, 1996), h. 53. 
berpikir dan bertindak, serta tidak merasa bergantung pada orang lain secara emosional. ${ }^{2}$

Jika ditinjau dari perspektif psikologis, menurut Luther kemandirian pada dasarnya berawal dari adanya rasa kemandirian diri (self-efficacy) atau persepsi seseorang tentang seberapa baik individu dapat menangani suatu masalah yang muncul. ${ }^{3}$ Kemandirian sebagai salah satu aspek yang ingin dicapai tidak akan muncul secara tiba-tiba, tetapi perlu dilatih dan membutuhkan proses yang panjang. Salah satu upaya untuk mencapainya adalah menciptakan suasana kondusif yang memungkinkan anak mengembangkan kemandirian tersebut. Kemandirian bukan hanya sekedar mandiri dalam arti sempit, melainkan juga dalam arti luas yaitu bagaimana anak mengalami dan melakukan kegiatan sosial.

Menurut Bathi, kemandirian merupakan perilaku yang aktivitasnya diarahkan kepada diri sendiri, tidak banyak mengharapkan bantuan dari orang lain, dan bahkan mencoba memecahkan masalahnya sendiri. ${ }^{4}$ Witherington dalam Spencer mengemukakan bahwa perilaku kemandirian ditunjukkan dengan adanya kemampuan untuk mengambil inisiatif, kemampuan mengatasi masalah serta keinginan untuk mengerjakan sesuatu tanpa bantuan orang lain. ${ }^{5}$ Sedangkan Lindzey dan Aronson menyatakan bahwa orang-orang yang mandiri menunjukkan inisiatif, berusaha untuk mengejar prestasi, menunjukkan rasa percaya diri yang besar, secara relatif jarang mencari perlindungan dari orang lain serta mempunyai rasa ingin menonjol. ${ }^{6}$ Mandiri adalah sikap yang mampu mengurus kehidupannya sendiri dan tidak menjadi beban orang lain. Sikap mandiri bukan sikap egois atau hidup sendiri, melainkan sikap bersedia dan mampu membangun kehidupan sendiri dalam rangka kebersamaan.

Kemandirian merupakan kemampuan penting dalam hidup seseorang yang perlu dilatih sejak dini. Seseorang dikatakan mandiri jika dalam

${ }^{2}$ Steven J. Stein and Howard E. Book, Ledakan EQ, Terjemahan Trinanda Rainy Januarsari dan Yudhi Murtanto (Bandung: Kaifa, 2000), h. 105.

${ }^{3}$ Fred Luther, Organizational Behavior (New York: Mc. Grow-Hill International Edition, 1995), h. 115.

${ }^{4}$ Bathi H.K, Educational Psyichology (New Delhi: The Macmillen company or India limited, 1977), h: 28.

5 Spencer and Koss, Persperctive in Child Psychology (New York: Mc.Grow Hill Book Company, 1970), h. 17.

${ }^{6}$ Lindzey G and Aronson E, The Handbook of Social Psychological (New Delhi: The Macmillan Limited Publishing, 1968), h. 218. 
menjalani kehidupan tidak tergantung kepada orang lain khususnya dalam melakukan kegiatan sehari-hari. Kemandirian juga ditunjukkan dengan adanya kemampuan mengambil keputusan serta mengatasi masalah. Dengan demikian setiap anak perlu dilatih untuk mengembangkan kemandirian sesuai kapasitas dan tahapan perkembangannya. Secara praktis kemandirian menurut Dowling adalah kemampuan anak dalam berpikir dan melakukan sesuatu oleh diri mereka sendiri untuk memenuhi kebutuhannya sehingga mereka tidak lagi bergantung pada orang lain namun dapat menjadi individu yang dapat berdiri sendiri. ${ }^{7}$

Kemandirian anak merupakan kemampuan anak untuk melakukan kegiatan dan tugas sehari-hari sendiri atau dengan sedikit bimbingan, sesuai dengan tahap perkembangan dan kemampuan anak. Kemandirian berarti bahwa anak telah mampu bukan hanya mengenal mana yang benar dan mana yang salah, tetapi juga mampu membedakan mana yang baik dan mana yang buruk. Pada fase kemandirian ini anak telah mampu menerapkan terhadap hal-hal yang menjadi larangan atau yang dilarang, serta sekaligus memahami konsekwensi resiko jika melanggar aturan. ${ }^{8}$

Definisi lain menurut Einon kemandirian anak usia dini ialah kemampuan anak untuk melakukan perawatan terhadap diri sendiri, seperti makan, berpakaian, ke toilet dan mandi. ${ }^{9}$ Kemandirian merupakan suatu sikap yang diperoleh secara kumulatif melalui proses yang dialami seseorang dalam perkembangannya. Dimana dalam proses menuju kemandirian, individu belajar untuk menghadapi berbagai situasi dalam lingkungannya sampai ia mampu berpikir dan mengambil tindakan yang baik dalam mengatasi setiap situasi. ${ }^{10}$

Carol Seefeldt menyatakan bahwa kebutuhan akan otonomi ditandai dengan sikap mental mandiri dan tidak mandiri. Kadang seorang anak ingin keluar dan mencoba melakukannya sendiri namun kadang ia ingin ibunya berada di dekatnya. ${ }^{11}$ Erikson (1968), seperti juga Mahler

\footnotetext{
7 Marion Dowling, Young Children's Personal, Social and Emotional Development, Second Edition (London: Paul Chapman Publishing, 2005), h. 41.

${ }^{8}$ Abdul Majid, Pendidikan Karakter (Bandung: PT. Rosdakarya, 2012), h. 26.

${ }^{9}$ Dorothy Einon, Learning Early (Jakarta: Grasindo, 2006), h. 204.

${ }^{10}$ Zainun Mutadin, "Kemandirian sebagai Kebutuhan Psikologis pada Remaja", E. Psikologi 2002. http://e-psikologi.com/ h.5.

${ }^{11}$ Carol Seefeldt dan Nita Barbour, Early Childhood Education (New Jersey: Prentice-Hill Inc, 1998), h. 47.
} 
percaya bahwa kemandirian adalah hal yang sangat penting dalam dua tahun pertama kehidupan seorang anak. Erikson menggambarkan tahap perkembangan yang ke dua ini sebagai tahap otonomi vs malu dan ragu-ragu. Otonomi anak dibangun melalui perkembangan mental dan kemampuan motorik. Ketika pengasuh kurang sabar dan melakukan apa yang sebenarnya anak mampu lakukan sendiri, maka yang berkembang adalah malu dan ragu-ragu. Erikson juga percaya bahwa tahap otonomi vs malu dan ragu-ragu mempunyai implikasi yang sangat penting dalam perkembangan kemandirian dan identitas anak selama masa remaja. Perkembangan otonomi selama tahun-tahun awal memberi keberanian bagi remaja untuk menjadi pribadi yang mandiri yang dapat membuat pilihan dan memimpin masa depannya sendiri. ${ }^{12}$

Erikson juga memandang tahap otonomi adalah masa anak belajar mandiri, bagi Mahler ini adalah masa anak belajar berpisah dari orang tuanya dengan percaya diri. Kedua teoris ini setuju bahwa ketika pada tahun-tahun awal jika anak tidak cukup percaya pada pengasuh dan kurang rasa individuasi, maka hal ini akan menjadi benih yang akan nampak dalam penyesuaian dirinya kelak. Ketika dewasa sulit mengembangkan kedekatan dengan seseorang, sangat mandiri terhadap orang yang dicintainya atau sebaliknya terus menerus ragu terhadap kemampuan dirinya untuk menemui tantangan baru. ${ }^{13}$

Dari beberapa definisi tentang kemandirian dapat disimpulkan bahwa kemandirian merupakan kemampuan seseorang untuk tidak tergantung atau tidak membutuhkan bantuan orang lain dalam merawat dirinya secara fisik (makan sendiri tanpa disuapi, berpakaian sendiri tanpa dibantu, mandi dan buang air besar serta kecil sendiri), dalam membuat sebuah keputusan secara emosi, dan dalam berinteraksi dengan orang lain secara sosial. Kemandirian anak usia dini merupakan bagian dari proses perkembangan yang diharapkan terjadi dalam rangka menuju ke kedewasaan, intinya bahwa kemandirian anak merupakan suatu kemampuan untuk berfikir, merasakan, serta anak melakukan sesuatu atas dorongan diri sendiri sesuai dengan kewajibannya dalam kehidupan sehari-hari tanpa dibantu oleh orang lain.

${ }^{12}$ John W. Santrock, Life-Span Development, Perkembangan Masa Hidup, Jilid 1 dan 2, Alih Bahasa, Achmad Chusairi (Jakarta: Erlangga, 2002), h. 202.

${ }^{13}$ Laura E. Berk, Infants, Children and Adolescents (Boston: Allyn and Bacon,1999), h. 257. 


\section{Ciri-ciri Kemandirian Anak}

Ciri khas kemandirian pada anak diantaranya mereka memiliki kecenderungan dan kemampuan dalam memecahkan masalah dari pada berkutat dalam kekhawatiran bila terlibat masalah. Anak yang mandiri tidak takut dalam mengambil resiko karena sudah mempertimbangkan hasil sebelum berbuat. Anak yang mandiri percaya terhadap penilaian sendiri, sehingga tidak sedikit-sedikit bertanya atau meminta bantuan. Anak yang mandiri memiliki kontrol yang lebih baik terhadap kehidupannya. Covey menegaskan bahwa kemandirian memiliki ciri-ciri, diantarnya: (1) secara fisik mampu bekerja sendiri, (2) secara mental dapat berpikir sendiri, (3) secara kreatif mampu mengekspresikan gagasannya dengan cara yang mudah dipahami, dan (4) secara emosional kegiatan yang dilakukannya dipertanggungjawabkan sendiri. ${ }^{14}$

Masrun dkk, membagi kemandirian ke dalam lima komponen yaitu sebagai berikut: (1) Bebas, artinya bertindak atas kehendaknya sendiri bukan karena orang lain dan tidak tergantung pada orang lain. (2) Progresif, artinya berusaha untuk mengejar prestasi, tekun dan terencana dalam mewujudkan harapannya. (3) Inisiatif, artinya mampu berpikir dan bertindak secara original, kreatif dan penuh inisiatif. (4) Terkendali dari dalam, artinya mampu mengatasi masalah yang dihadapi, mampu mengendalikan tindakannya serta mampu mempengaruhi lingkungan atas usahanya sendiri. (5) Kemantapan diri (harga diri dan percaya diri), artinya mempunyai rasa percaya terhadap kemampuan diri sendiri, menerima dirinya dan memperoleh kepuasan dari usahanya. ${ }^{15}$

\section{Aspek-aspek Kemandirian}

Menurut Havinghurst dalam Mu'tadin, ${ }^{16}$ kemandirian dalam konteks individu memiliki aspek yang lebih luas dari sekedar aspek fisik, yaitu: aspek emosi ditunjukkan dengan kemampuan mengontrol emosi, asek ekonomi ditunjukkan dengan kemampuan mengatur ekonomi dan tidak tergantung kebutuhan ekonomi pada orang tua, aspek intelektual ditunjukkan dengan kemampuan mengatasi berbagai masalah yang dihadapi dan aspek sosial

\footnotetext{
14 Steven R. Covey, The Seven Habits of Highly Effective People, terjemahan Budijanto (Jakarta: Binarupa Aksara, 1997), pp. 38-39.

15 www.lib.ug.co.id diunduh tanggal 23 Nopember 2014.

16 Zainun Mutadin, "Kemandirian sebagai Kebutuhan Psikologis pada Remaja”, h.5
} 
ditunjukkan dengan kemampuan berinteraksi dengan orang lain.

Ara ${ }^{17}$ mengemukakan aspek-aspek kemandirian anak adalah sebagai berikut: (1) Kebebasan, merupakan hak asasi bagi setiap manusia, begitu juga seorang anak. Anak cenderung akan mengalami kesulitan untuk mengembangkan kemampuan dirinya dan mencapai tujuan hidupnya, bila tanpa kebebasan. Perwujudan kemandirian seseorang dapat dilihat dalam kebebasannya membuat keputusan. (2) Inisiatif, merupakan suatu ide yang diwujudkan ke dalam bentuk tingkah laku. Perwujudan kemandirian seseorang dapat dilihat dalam kemampuannya untuk mengemukakan ide, berpendapat, memenuhi kebutuhan sendiri dan berani mempertahankan sikap.(3) Percaya Diri, merupakan sikap individu yang menunjukkan keyakinan bahwa dirinya dapat mengembangkan rasa dihargai. Perwujudan kemandirian anak dapat dilihat dalam kemampuan untuk berani memilih, percaya akan kemampuannya dalam mengorganisasikan diri dan menghasilkan sesuatu yang baik. (4) Tanggung Jawab, merupakan aspek yang tidak hanya ditujukan pada diri anak itu sendiri tetapi juga kepada orang lain. Perwujudan kemandirian dapat dilihat dalam tanggung jawab seseorang untuk berani menanggung resiko atas konsekuensi dari keputusan yang telah diambil, menunjukkan loyalitas dan memiliki kemampuan untuk membedakan atau memisahkan antara kehidupan dirinya dengan orang lain di dalam lingkungannya. (5) Ketegasan Diri, merupakan aspek yang menunjukkan adanya suatu kemampuan untuk mengandalkan dirinya sendiri. Perwujudan kemandirian seseorang dapat dilihat dalam keberanian seseorang untuk mengambil resiko dan mempertahankan pendapat meskipun pendapatnya berbeda dengan orang lain. (6) Pengambilan Keputusan, dalam kehidupannya anak selalu dihadapkan pada berbagai pilihan yang memaksanya mengambil keputusan untuk memilih. Perwujudan kemandirian seorang anak dapat dilihat di dalam kemampuan untuk menemukan akar permasalahan, mengevaluasi segala kemungkinan di dalam mengatasi masalah dan berbagai tantangan serta kesulitan lainnya, tanpa harus mendapat bantuan atau bimbingan dari orang yang lebih dewasa. (7) Kontrol Diri, merupakan suatu kemampuan untuk menyesuaikan diri dengan lingkungan sosialnya, baik dengan mengubah tingkah laku atau menunda tingkah laku. Dengan kata lain sebagai kemampuan untuk mengontrol diri dan perasaannya, sehingga seseorang tidak merasa takut,

\footnotetext{
${ }^{17}$ Ara, 1998 diakses melalui www.papers.gunadarma.ac.id diunduh tanggal 23 Nopember 2014.
} 
tidak cemas, tidak ragu atau tidak marah yang berlebihan saat dirinya berinteraksi dengan orang lain atau lingkungannya.

Masih banyak aspek atau bentuk kemandirian anak usia dini, namun dari penjelasan dan uraian di atas, dapat disimpulkan bahwa ada tiga aspek atau bentuk kemandirian anak usia dini yaitu: kemandirian fisik, kemandirian emosional dan kemandirian sosial. Kemandirian secara fisik dalam konteks keterampilan hidup yaitu apabila anak sudah dapat melakukan hal-hal sederhana dalam rangka merawat dirinya tanpa perlu bantuan orang lain. Seperti makan, minum, berpakaian dan buang air dapat dilakukannya sendiri. Kemandirian emosional ketika anak mampu mengatasi perasaannya sendiri khususnya perasaan negatif seperti takut dan sedih dan anak juga dapat merasa aman dan nyaman dengan dirinya sendiri tanpa harus didampingi orang lain di sekitarnya. Kemandirian sosial ditandai dengan kemampuan anak, bersosialisasi dengan lingkungan di sekitarnya, misalnya dapat dengan sabar menunggu giliran, dapat bergantian ketika bermain. Anak mampu berinteraksi dengan anak lain ataupun dengan orang dewasa.

\section{Faktor-faktor yang Mempengaruhi Kemandirian Anak}

Menurut Santrock ${ }^{18}$ faktor-faktor yang mempengaruhi kemandirian dan membentuk kemandirian adalah: (1) Lingkungan. Lingkungan keluarga (internal) dan masyarakat (eksternal) akan membentuk kepribadian seseorang termasuk kemandirian (2) Pola Asuh. Peran dan pola asuh orang tua sangat berpengaruh dalam penanaman nilai-nilai kemandirian seorang anak (3) Pendidikan. Pendidikan memiliki sumbangan yang berarti dalam perkembangan terbentuknya kemandirian pada diri seseorang yakni (1) Interaksi social. Interaksi sosial melatih anak menyesuaikan diri dan bertanggungjawab atas apa yang dilakukan sehingga diharapkan anak mampu menyelesaikan masalah yang dihadapi (2) Intelegensi. Intelegensi merupakan faktor penting yang berpengaruh terhadap proses penentuan sikap, pengambilan keputusan, penyelesaian masalah serta penyesuaian diri

Hasan Basri berpendapat bahwa faktor-faktor yang dapat mempengaruhi pembentukkan kemandirian anak adalah sebagai berikut: ${ }^{19}$

\footnotetext{
${ }^{18}$ John W. Santrock, Adolesence Perkembangan Remaja (Jakarta: Erlangga, 2003), h. 145-220.

${ }^{19}$ Hasan Basri, Remaja Berkualitas Problematika Remaja dan Solusinya (Yogyakarta: Pustaka Pelajar, 1996), h. 53.
} 


\section{1) Faktor Internal}

Faktor internal merupakan semua pengaruh yang bersumber dari dalam diri anak itu sendiri, seperti keadaan keturunan dan konstitusi tubuhnya sejak dilahirkan dengan segala perlengkapan yang melekat padanya. Faktor internal terdiri dari; (a) Faktor Peran Jenis Kelamin, secara fisik anak laki-laki dan wanita tampak jelas perbedaan dalam perkembangan kemandiriannya. Dalam perkembangan kemandirian, anak laki-laki biasanya lebih aktif dari pada anak perempuan, (b) Faktor Kecerdasan atau Intelegensi, anak yang memiliki intelegensi yang tinggi akan lebih cepat menangkap sesuatu yang membutuhkan kemampuan berpikir, sehingga anak yang cerdas cenderung cepat dalam membuat keputusan untuk bertindak, dibarengi dengan kemampuan menganalisis yang baik terhadap resiko-resiko yang akan dihadapi. Intelegensi berhubungan dengan tingkat kemandirian anak, artinya semakin tinggi intelegensi seorang anak maka semakin tinggi pula tingkat kemandiriannya, (c) Faktor Perkembangan, kemandirian akan banyak memberikan dampak yang positif bagi perkemangan anak. Oleh karena itu, orang tua perlu mengajarkan kemandirian sedini mungkin sesuai denag kemampuan perkembangan anak.

2) Faktor Eksternal

Faktor eksternal merupakan pengaruh yang berasal dari luar dirinya, sering pula dinamakan faktor lingkungan. Lingkungan kehidupan yang dihadapi anak sangat mempengaruhi perkembangan kepribadiannya, baik dalam segi-segi negatif maupun positif. Biasanya jika lingkungan keluarga, sosial dan masyarakatnya baik, cenderung akan berdampak positif dalam hal kemandirian anak terutama dalam bidang nilai dan kebiasaan dalam melaksanakan tugas-tugas kehidupan. Faktor eksternal terdiri dari; (a) Faktor Pola Asuh, untuk bisa mandiri seseorang membutuhkan kesempatan, dukungan dan dorongan dari keluarga serta lingkungan sekitarnya, untuk itu orang tua dan respon dari lingkungan sosial sangat diperlukan bagi anak untuk setiap perilaku yang telah dilakukannya, (b) Faktor Sosial Budaya, merupakan salah satu faktor eksternal yang mempengaruhi perkembangan anak, terutama dalam bidang nilai dan kebiasaankebiasaan hidup akan membentuk kepribadiannya, termasuk pula dalam hal kemandiriannya, terutama di Indonesia yang terdiri dari 
berbagai macam suku bangsa dengan latar belakang sosial budaya yang beragam, (c) Faktor Lingkungan Sosial Ekonomi, faktor sosial ekonomi yang memadai dengan pola pendidikan dan pembiasaan yang baik akan mendukung perkembangan anak-anak menjadi mandiri. ${ }^{20}$

\section{Melatih Kemandirian Anak}

Menurut Tassoni banyak hal yang dapat dilakukan sepanjang hari untuk mendorong anak bertindak mandiri. Namun hal ini bukan berarti meninggalkan anak untuk melakukannya sendiri. Beberapa hal yang dapat menolong anak menjadi mandiri melalui kegiatan bermain diantaranya; (1) Mendorong anak membereskan mainannya sendiri, (2) Mendorong anak untuk memilih mainannya sendiri, (3) Mengijinkan anak berlatih mengenakan pakaian dengan menyediakan baju-baju yang menarik bagi anak untuk dipakaikan, (4) Mendorong anak untuk membersihkan meja bila kotor, (5) Memuji anak jika mereka sudah mencoba untuk menjadi mandiri. $^{21}$

Aktivitas makan juga dapat menolong anak menjadi mandiri, menurut Hendricks bukan hanya aktivitas makannya saja, namun bisa juga dilatih untuk menyediakan makanan, untuk melayani, membuat pilihan, membersihkan meja dan sebagainya. Salah satu cara untuk menolong anak memiliki kemandirian yang berkaitan dengan aktivitas makan adalah memberi keyakinan bahwa mereka tidak perlu menunggu untuk disuapi. ${ }^{22}$ Berk juga menyatakan bahwa keterampilan merawat diri anak usia dini, berangsur-angsur berkembang menjadi mahir berpakaian dan makan. Anak usia 2 tahun sudah dapat meletakkan dan mengambil baju. Anak usia 3 tahun sudah dapat buang air kecil dan buang air besar sebagaimana diperlukan. Antara usia 4-5 tahun sudah dapat mengenakan dan melepaskan baju tanpa pengawasan. Anak juga dapat menggunakan sendok ketika makan, bahkan usia 4 tahun sudah dapat menggunakan garpu dan usia 5-6 tahun sudah dapat menggunakan pisau untuk memotong makanan yang lembut. Mengancingkan baju dan menaikkan resleting juga

\footnotetext{
${ }^{20}$ Hasan Basri, Remaja Berkualitas Problematika Remaja dan Solusinya, .h.53

${ }^{21}$ Penny Tassoni, Diploma Child Care and Education (Oxford: Heinemann Educational Publishers, 2002), p. 417.

${ }^{22}$ Joanne Hendrick, The Whole Child (New Jersey: Marrill Prentice Hall, 1996), h. 74.
} 
sudah mampu dilakukan anak usia pra sekolah. Pada anak usia 6 tahun keterampilan merawat diri sudah lebih rumit seperti memakai sepatu bertali sendiri. Mereka sangat puas bisa mengatur tubuh mereka sendiri. Mereka bangga akan kemandirian mereka dan keterampilan baru mereka ini juga akan membuat hidup lebih mudah ketika dewasa kelak. Namun orang tua perlu kesabaran akan kemampuan anak-anak mereka. Ketika anak lelah dan tergesa-gesa, mereka akan makan dengan tangan mereka sendiri, memakai baju terbalik, memakai sepatu kiri di kaki kanan dan sebagainya. ${ }^{23}$

Untuk melatih kemandirian anak, selain menyediakan kesempatan yang sesuai dengan umur anak (menyelesaikan tugas sendiri, membuat keputusan) juga perlu menyediakan bantuan hanya jika mereka minta. Kadang anak minta bantuan ketika mereka sebenarnya hanya minta ditemani atau diperhatikan. ${ }^{24}$ Anak perlu didorong untuk melakukan sesuatu sendiri yang mereka dapat lakukan. Ada perbedaan antara melakukan untuk (doing to) dengan melakukan bagi (doing for) anak. Perlu menahan diri untuk menunggu anak menaikkan resleting, mengerti kapan anak perlu dibantu tanpa diambil alih, tidak berbicara terlalu banyak saat anak sedang berusaha belajar. Membangun kompetensi pada diri anak dengan membiarkan anak melakukannya sendiri, akan meningkatkan harga diri yang selanjutnya dapat melatih pengendalian diri anak. ${ }^{25}$ Mengijinkan anak mengalami "penguasaan" dengan membuat keputusan sendiri dan menjadi mandiri adalah dua cara untuk mendorong terbentuknya kompetensi. Maccoby (1980) mengatakan bahwa mendorong anak untuk membuat pilihan dan keputusan melakukan sesuatu bagi diri mereka sendiri akan mengurangi rasa tidak mampu dan meningkatkan perasaan mampu dan mengembangkan standar pencapaian yang logis. ${ }^{26}$

Dapat disimpulkan bahwa sejak dini anak sudah memiliki kapasitas untuk mengembangkan kemandirian. Oleh karena itu, orang tua harus memberi kesempatan bagi anak untuk mengembangkan kemandiriannya dengan mencoba keterampilan baru. Misalnya memberi kesempatan menggunakan peralatan makan, memilih baju kesukaan, membuka kemasan

${ }^{23}$ Laura E. Berk, Infants, Children and Adolescents (Boston: Allyn and Bacon, 1999), h. 313.

${ }^{24}$ T.M. McDevitt dan J.E. Ormrod, Child Development and Education (New Jersey: Merrill Prentice Hall, Pearson Education, 2002), h. 432.

${ }^{25}$ Joanne Hendrick, The Whole Child,h. 18.

${ }^{26}$ Joanne Hendrick, The Whole Child, h. 148. 
atau bungkusan dan banyak hal-hal kecil lainnya. Perasaan berhasil dalam melakukan sesuatu pada akhirnya akan memunculkan rasa senang dan percaya diri, sehingga anak tidak takut mencoba keterampilan baru lainnya.

\section{Kemandirian dan Harga Diri}

Bee menyatakan "too much control and the child will not have sufficient opportunity to explore, too little control and the child will become unmanageable and fail to learn the social skill he will need to get along with peers as well as adults", terlalu banyak pengawasan mengakibatkan anak tidak akan cukup kesempatan untuk mengeksplorasi, terlalu sedikit pengawasan anak juga akan menjadi tidak mampu mengatur dirinya dan gagal belajar bersosialisasi yang dibutuhkan ketika bergaul dengan teman sebaya sebaik orang dewasa. ${ }^{27}$ Kemudian Hurlock menegaskan bahwa semakin banyak anak melakukan sendiri, semakin besar kebahagiaan dan rasa percaya atas dirinya. Kebergantungan menimbulkan kekecewaan dan ketidakmampuan diri. ${ }^{28}$

Apabila anak-anak tidak diberi kesempatan mempelajari keterampilan tertentu, dimana perkembangannya sudah memungkinkan dan anak ingin melakukan karena berkembangnya keinginan untuk mandiri, maka mereka tidak saja kurang memiliki dasar keterampilan yang telah dipelajari teman-teman sebayanya tetapi juga akan kurang memiliki motivasi untuk mempelajari berbagai keterampilan pasa saat diberi kesempatan. ${ }^{29}$ Tassoni mengemukakan bahwa anak yang merasa positif tentang dirinya memiliki harga diri yang tinggi. Hal ini berarti mereka mereka lebih suka mencoba hal-hal yang baru, siap meminta pertolongan dan mudah berteman. Anakanak dengan harga diri yang rendah kurang percaya diri dan mudah menyerah jika mereka pikir mereka akan gagal. Kadang-kadang anak dengan harga diri yang rendah dengan sengaja berkelakuan tidak baik karena mereka takut mencoba hal-hal yang sulit dan akhirnya gagal. ${ }^{30}$

${ }^{27}$ Helen Bee, The Growing Child (New York: Longman Addison-Wesley Educational Publishers, 1999), p. 290.

${ }^{28}$ Elizabeth B. Hurlock, Perkembangan Anak, Jilid 1. Terjemahan Meitsari Tjandrasa (Jakarta: Erlangga, 2008), h. 150.

${ }^{29}$ Elizabeth B. Hurlock, Developmental Psychology, Psikologi Perkembangan Suatu Pendekatan Sepanjang Rentang Kehidupan, Edisi Kelima. Terjemahan Istiwidayanti \& Soedjarwo (Jakarta: Erlangga, 1991), h. 111.

${ }_{30}$ Penny Tassoni, Diploma Child Care and Education (Oxford: Heinemann Educational Publishers, 2002), h. 251. 
Hendrick ${ }^{31}$ menyatakan jika orang tua melakukan terlalu banyak bagi anaknya, akan menyebabkan harga diri anak rendah. Sekalipun orang tua memiliki alasan untuk menghemat waktu atau pekerjaan dapat dikerjakan denga cepat dan tepat, namun lebih baik menunggu dan membiarkan anak melakukan sesuatu untuk dirinya sendiri, yang mana akan memberi kesempatan kepada anak untuk merasakan kemenangan akan kemandirian dan akhirnya membawa kepada pencapaian.

Berdasarkan pendapat para ahli tentang kemandirian, ciri-ciri kemandirian anak, aspek-aspek kemandirian, faktor-faktor yang mempengaruhi kemandirian anak, melatih kemandirian anak, serta kemandirian dan harga diri sebagaimana uraian di atas, dapat disimpulkan bahwa kemandirian adalah kemampuan anak untuk tidak tergantung pada bantuan orang lain dalam merawat dirinya secara fisik, dalam membuat keputusan secara emosi dan dalam berinteraksi dengan orang lain secara sosial.

\section{Penutup}

Kemandirian merupakan suatu kemampuan yang dimiliki anak untuk melakukan segala sesuatu secara mandiri, baik yang terkait dengan aktivitas diri sendiri maupun aktivitas dalam kesehariannya, tanpa harus tergantung sepenuhnya pada orang lain. Dengan kemandirian yang tinggi anak akan lebih leluasa dan lebih bebas untuk bergerak kesana kemari untuk mempelajari dan berinteraksi dengan lingkungan disekitar mereka. Dengan sikap yang mandiri pada anak akan membuat anak lebih percaya diri untuk melakukan semuanya dengan bebas.

Kemandirian akan membuat anak mudah untuk melakukan kegiatan bermain dan berinteraksi secara baik, anak akan mudah untuk diajak bekerja sama dan berkomunikasi. Sikap kemandirian pada anak sangat erat terkait dengan kecerdasan sosial mereka, kemandirian tidak merefleksikan sikap individualistik atau egois pada anak sehingga mereka lebih mudah untuk bergaul dengan teman dan lingkungannya. Seperti yang dikemukakan oleh Hurlock bahwa semakin banyak anak melakukan sendiri, semakin besar kebahagiaan dan rasa percaya atas dirinya. Kebergantungan menimbulkan kekecewaan dan ketidakmampuan diri.

Apabila anak tidak diberi kesempatan untuk mempelajari keterampilan

${ }^{31}$ Joanne Hendrick, The Whole Child, h. 143. 
tertentu, dimana perkembangannya sudah memungkinkan, dan anak ingin melakukan karena berkembangnya keinginan untuk mandiri, maka mereka akhirnya tidak saja kurang memiliki dasar keterampilan yang telah dipelajari teman-teman sebayanya tetapi juga akan kurang memiliki motivasi untuk mempelajari berbagai keterampilan saat diberi kesempatan.

\section{Pustaka Acuan}

Basri, Hasan, Remaja Berkualitas Problematika Remaja dan Solusinya, Yogyakarta: Pustaka Pelajar, 1996.

Bathi H.K, Educational Psyichology. New Delhi: The Macmillen company or India limited, 1977.

Bee, Helen, The Growing Child. New York: Longman Addison-Wesley Educational Publishers, 1999.

Berk, Laura E., Child Development, Seventh Edition: Illinois State University, Pearson, 2007.

Berk, Laura E., Infants, Children and Adolescents. Boston: Allyn and Bacon, 1999.

Covey, R., Steven, The Seven Habits of Highly Effective People, terjemahan Budijanto. Jakarta: Binarupa Aksara, 1997.

Dowling, Marion, Young Children's Personal, Social and Emotional Development, Second Edition. London: Paul Chapman Publishing, 2005.

Einon, Dorothy, Learning Early. Jakarta: Grasindo, 2006.

Hendrick, Joanne, The Whole Child. New Jersey: Marrill Prentice Hall, 1996.

www.lib.ug.co.id diunduh tanggal 23 Nopember 2014.

Hurlock, Elizabeth B. Developmental Psychology, Psikologi Perkembangan Suatu Pendekatan Sepanjang Rentang Kehidupan, Edisi Kelima. Terjemahan Istiwidayanti \& Soedjarwo, Jakarta: Erlangga, 1991. , Perkembangan Anak, Jilid 1. Terjemahan Meitsari Tjandrasa. Jakarta: Erlangga, 2008.

Lindzey G and Aronson E, The Handbook of Social Psychological. New Delhi: The Macmillan Limited Publishing, 1968.

Luther, Fred, Organizational Behavior, New York: Mc. Grow-Hill International Edition, 1995. 
Majid, Abdul., Pendidikan Karakter. Bandung: PT. Rosdakarya, 2012.

McDevitt TM., and J.E. Ormrod, Child Development and Education. New Jersey: Merrill Prentice Hall, Pearson Education, 2002.

Mutadin, Zainun, "Kemandirian sebagai Kebutuhan Psikologis pada Remaja", E. Psikologi 2002. http://e-psikologi.com/ par.5.

Santrock, John W., Adolesence Perkembangan Remaja, Jakarta: Erlangga, 2003.

, Educational Psychology, Psikologi Pendidikan, Edisi Ketiga, Jakarta: Erlangga, 2009.

, Life-Span Development, Perkembangan Masa Hidup, Jilid 1 dan 2, Alih Bahasa, Achmad Chusairi, Jakarta: Erlangga, 2002.

Seefeldt, Carol and Nita Barbour, Early Childhood Education. New Jersey: Prentice-Hill Inc, 1998.

Spencer and Koss, Persperctive in Child Psychology, New York: Mc.Grow Hill Book Company, 1970.

Stein, J., Steven and Howard E. Book, Ledakan EQ, Terjemahan Trinanda Rainy Januarsari dan Yudhi Murtanto, Bandung: Kaifa, 2000.

Tassoni, Penny, Diploma Child Care and Education. Oxford: Heinemann Educational Publishers, 2002. 